\title{
Preparation of dielectric greases from some inorganic thickeners
}

\author{
A. M. Hassan ${ }^{1}$, M. A. Youssif ${ }^{1}$, A. M. Mazrouaa ${ }^{1,}{ }^{*}$, R. M. Abou Shahba ${ }^{2}$, M. A. E. Youssif ${ }^{1}$ \\ ${ }^{1}$ Egyption Petroleum Research Institute, Nasr City 11727, Cairo, Egypt \\ ${ }^{2}$ Al-Azhar University, Faculty of Science, Nasr City, Cairo, Egypt
}

Email address:

azza_mazroua2005@yahoo.com(A.M. Mazrouaa)

To cite this article:

A. M. Hassan, M. A. Youssif, A. M. Mazrouaa, R. M. Abou Shahba, M.A.E. Preparation of Dielectric Greases from Some Inorganic Thickeners. American Journal of Applied Chemistry. Vol. 1, No. 1, 2013, pp. 9-16. doi: 10.11648/j.ajac.20130101.12

\begin{abstract}
According to this study wax gel grease $\left(\mathrm{S}_{0}\right)$ is formulated from base lube oil grade 260/290, transformer oil, microcrystalline wax, additives ( $0.1-2 \%)$ of Polyoxyethylene sorbiton-nano-palmitate antioxidant and $2,2^{`}$ methylene bis (4-methyl-6-tertiary butyl phenol) anticorrosion, was found that it had not well enough physico-chemical and dielectric properties, so other thicker may be used as (nano talc, nano kaolin, sodium silicate, ultramarine and silica from rice husk) and added to wax gel in certain proportions in an attempt to improve its physico-chemical properties (viscosity, penetration, dropping point and water resistance) and dielectric properties (dielectric constant, dielectric loss and volume resistivity) at frequency ranging $1-1000 \mathrm{KHz}$ at $35^{\circ} \mathrm{C}$. Grease includes nano talc and silica from rice husk which has the best dielectric properties.
\end{abstract}

Keywords: Nano Talc Grease, Nano Kaolin Grease, Sodium Silicate Grease, Ultramarine Grease, Silica From Rice Husk Grease

\section{Introduction}

Grease is the most widely used lubricant for roller bearings and low viscosity applications mainly because grease type lubricants are relatively easy to handle and require only the simplest sealing devices ${ }^{(1,2)}$ A lubricating grease has extreme pressure properties comprising a major amount of lubricating oil and minor amount of colloidal asbestos finely it is divided into polymeric fluorocarbon powder and powdered inorganic grease thickener. The inorganic thickeners are selected from the group consisting of talc, graphite and groups I, $\Pi$ and IV of metal oxides and carbonates ${ }^{(3)}$.Dielectric grease also provides oxidation and heat stability and can withstand a wide temperature range without breaking down. Dielectric grease is used to dissipate heat from some electronic component and is also useful in lubricating machines such as slide contact switches and relay contacts. It is used in electrical transformers also can include other components to enhance the life and function of the transformer oil ${ }^{(4-7)}$.A grease composition for use as cable filling materials which contain about 75 to 95 parts by weight of a base component of a polyol or ester having a molecular weight of at least about 3000 and about 2 to 20 parts by weight of colloidal particle such as silica, clay or mixture thereof. Optionally about 1 to 3 parts by weight of an antioxidant ${ }^{(8)}$.Using synthetic dielectric greases on the pins, blades, and sockets of separable electrical connectors goes a long way toward preventing wear, sealing out the environment, improving performance, and extending the operating life of your electrical device ${ }^{(9)}$.Many years experience in Britain had shown that petroleum jelly, used as an insulator coating, is an effective against flash over in polluted localities. The broad classes of satisfactory material are petroleum jellies, silicon greases are strippable compounds. Petroleum jellies were originally made from a wide range of petroleum fractions, but they are now generally compounded from hydrocarbon oils and microcrystalline waxes. Materials with similar characteristics, containing some synthetic waxes, have also been included in this category. They are often characterized by increasing the temperature and melting at sites of discharges. Silicon grease are composed of silica filler and silicon oil, which are the active component. They don't melt but they decompose at temperature above $200^{\circ} \mathrm{C}^{(10,11)}$.A grease is consisting of ( 77 to $95 \%$ ) by weight of paraffinic or naphthenic oil, colloidal particle filler ( 2 to $15 \%$ ) by weight of hydrophobic or hydrophilic fused silica, a bleed inhibitor and optionally up to (15\%) by weight of copolymer. The grease can advantageously be used as a cable filling material, 
especially for optical fiber cable ${ }^{(12)}$.

The aim of this study is to improve the electrical properties of wax gel $\left(\mathrm{S}_{0}\right)$ and directing it to be a good electrical insulators, so atactic polypropylene in mixture with any of the following (ultramarine, silica from rice husk, nano kaolin, nano talc or sodium silicate) are formulated together in certain concentration.

\section{Expermental Work}

Materials supplied from:

Misr petroleum company, Gamra, Cairo, Egypt; Petroleum chemical company, Alameria, Alexandria, Egypt.

\subsection{Materials}

Base lube oil grade (260/290); transformer oil; microcrystalline wax; silicon dioxide (particle size: $140 \mu \mathrm{m}$ ); Polyoxy ethylene sorbiton-nano-palmitate, Tween (20); -2, 2 ' methylen-bis(4-methyl-6-tertiary butyl phenol).

Natural rice husk: (Silica 8.8-13.3, Ash 13.4-20.4\%, Fiber 65.3-68.9\%). Nano-magnesium silicate: (talc) $\mathrm{Mg}_{2} \quad \mathrm{Si}_{4} \mathrm{O}_{10}$ $(\mathrm{OH})_{2}$, particle size $100 \mathrm{~nm}$. Nano-kaolin $\mathrm{Al}_{2} \mathrm{O}_{3} \cdot 2 \mathrm{SiO}_{2} \cdot 2 \mathrm{H}_{2} \mathrm{O}$, particle size: $70 \mathrm{~nm}$. Ultramarine $\mathrm{Na}_{8-10}$

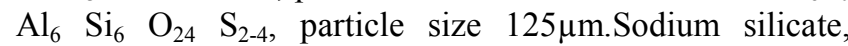
$\mathrm{Na}_{2} \mathrm{SiO}_{3}$.

\subsection{Methods}

Dielectric and resistivity measurement

The computerized LRC (Hioki model 3531 Z Hi Tester) was used to conduct the electrical properties of the investigated samples. The bridge measures the capacitance from $19 \mathrm{pF}$ up to $370 \mathrm{mf}$, the resistance from $100 \mathrm{~m} \Omega$ up to $200 \mathrm{M} \Omega$ and the dielectric loss $\left(\varepsilon^{\prime \prime}\right), \tan (\delta)$ from $10^{-5}$ up to 101.

The relative dielectric permittivity was calculating using the relations:

$$
\varepsilon^{\prime}=\mathrm{Cm} / \mathrm{C} 0
$$

$\varepsilon^{\prime \prime}=\varepsilon ` \tan \delta$

Where $\mathrm{Cm}$ : the measured capacitance of the used material

$\mathrm{C} 0$ : the capacity of the empty condenser.

$\varepsilon$ ": the dielectric loss,

$\tan \delta$ : the loss tangent.

The resistivity is calculating using the equation

$\mathrm{R}=\rho \mathrm{L} / \mathrm{A}, \rho=1 / \sigma$

Where $\rho$ is the resistivity ohm.cm. L is the length of the sample in $\mathrm{mm}, \mathrm{A}$ is the cross sectional area, and $\sigma$ is the electrical conductivity (13).

Dynamic viscosity

The apparent viscosities of the prepared greases were carried out by digital Rheometer LVDV-Ш- Ultra ASTM.

Infrared spectroscopy (IR)

FTIR spectrometer (Fourier transform infrared, ATI Maston Gensis FTIRTM). At wave number from 500-4000 $\mathrm{cm}-1$ and transmittance from 12 to $26 \%$.

Dropping point

The dropping point tests of the prepared greases measured according to ASTM D - 566 methods.

Penetration

Penetration was determined by using ASTM D - 217.

Flash point

Flash point was determined by using open system of ASTM D - 92.

Table (1) Formulation of the prepared samples $W G_{1}, W G_{2}, W G_{3}$ and $\mathrm{WG}_{4}$ wax gel

\begin{tabular}{lllll}
\hline \multirow{2}{*}{ Constituent parts by weight, $\mathbf{g}$} & \multicolumn{4}{l}{ Sample Notation } \\
& $\mathbf{W G}_{\mathbf{1}}$ & $\mathbf{W G}_{\mathbf{2}}$ & $\mathbf{W G}_{\mathbf{3}}$ & $\mathbf{W G}_{\mathbf{4}}$ \\
Base lube oil grad (260/290)\} & 167.26 & 167.26 & 167.26 & 167.26 \\
Transformer oil & 83.63 & 83.63 & 83.63 & 83.63 \\
Ratio & $2: 1$ & $2: 1$ & $2: 1$ & $2: 1$ \\
Lube oil blend & 250.9 & 250.9 & 250.9 & 250.9 \\
Microcrystalline wax & 250.9 & 135.62 & 109 & 62.73 \\
Ratio & $1: 1$ & $1.85: 1$ & $2.3: 1$ & $4: 1$ \\
\hline
\end{tabular}

Table (2) Specification of the prepared wax gels WG1,WG2,WG3 and WG4

\begin{tabular}{|c|c|c|c|c|}
\hline Specification & $\begin{array}{l}\text { Sample Not } \\
\mathbf{W G}_{1}\end{array}$ & $\mathbf{W G}_{\mathbf{2}}$ & $\mathbf{W G}_{3}$ & $\mathbf{W G}_{4}$ \\
\hline Colour & Pale yellow & Pale yellow & Pale yellow & Pale yellow \\
\hline Oil bleeding & Non & Non & Non & Non \\
\hline Extensibility & Slight & Large & Large & Large \\
\hline $\begin{array}{l}\text { Penetration, } 25^{\circ} \mathrm{C}, 10 \mathrm{~mm} / \\
\text { cone ( unworked) (126) }\end{array}$ & 125 & 190 & 250 & 180 \\
\hline Dropping point,${ }^{\circ} \mathrm{C}(127)$ & 72 & 62 & 59 & 60 \\
\hline Dynamic viscosity, at $66^{\circ} \mathrm{C}, \mathrm{cp}(128)$ & 83.35 & 47.88 & 29.08 & 50.81 \\
\hline Behavior at high temperature & Melted & Melted & Melted & Melted \\
\hline
\end{tabular}

\subsection{Preparation}

\subsubsection{Preparation of Wax Gel (Wax-Oil Mixture)}

In this experiment two types of oils had been used, the first was a base lube oil grade (260/290) and the second was transformer oil.

Lube base oil and transformer oil in the ratio $2: 1$ by weight were mixed under stirring at $110^{\circ} \mathrm{C}$ for 30 minutes to produce the lube oil blend. The physico-chemical characteristics of these oils were carried out using ASTM standard methods.

The lube oil blend was mixed with microcrystalline wax (Alexandria for petroleum company), under stirring at $100-120^{\circ} \mathrm{C}$ for 30 minutes with different ratios $1: 1,1.85: 1$, 
2.3:1 and 4:1 respectively (13). After cooling, the mixture turned to thicker gel. The obtained samples were denoted by WG1, WG2, WG3 and WG4 respectively. The formulation and specification were given in tables $(1,2)$.

\subsubsection{Preparation of Greases Containing Wax Gel $\left(S_{0}\right)$}

Oil blend $250.9 \mathrm{~g}$ (base lube oil $167.27 \mathrm{~g}$ and transformer oil $83.63 \mathrm{~g}$ ) was heated to $110-120^{\circ} \mathrm{C}$ and the microcrystalline wax $109 \mathrm{~g}$ was added portion wise under stirring for 30 minutes, followed by adding of 2,2 . methylene bis (4-methyl-6-tertiary butyl phenol) $1.4 \mathrm{~g}$ as antioxidant and Polyoxyethylene sorbiton-nano-palmitate $1.4 \mathrm{~g}$ as anticorrosion additives and stirring was continued to disperse the additives. After cooling the mixture was thickened to grease S0 (13). The formulation of sample S0 grease was shown in table (3). The specification of the resulted $\mathrm{S} 0$ grease was given in table (4).

\subsubsection{Preparation of Silica from Rice Husk}

Natural rice husk, a by-product of the rice milling industry, was used for preparing a series of modified rice husk using various concentration of $\mathrm{KOH}$ according to the following steps: natural rice husk was stirred with $\mathrm{KOH}(0.5-7.0 \%)$ at weight ratio 1:12 and heated to boil for 30 minutes then the mixture was left over night. The filtrate was washed twice with doubly distilled water and $10 \% \mathrm{HCl}$ was added $(\sim 100$ $\mathrm{ml})$.

The formed precipitate of silica was washed, dried at $105^{\circ} \mathrm{C}$ and thus the silica extracted by alkaline treatment has $\mathrm{pH} 3.3$ with small surface area $13 \mathrm{~m}^{2} / \mathrm{g}$ and large pore volume $35.5 \mathrm{ml} / \mathrm{g}$, the product was burned at $\left(700-800^{\circ} \mathrm{C}\right)$ to obtain a powdered of silica $\left(\mathrm{SiO}_{2}\right)(14)$. IR spectrum was shown in fig (1).

\subsubsection{Preparation of Grease $\left(S_{1}\right)$}

This type of greases employed a lube oil blend $(250.9 \mathrm{~g})$ and microcrystalline wax $103.5 \mathrm{~g}$. The composition were formulated by heating the mixture to $100^{\circ} \mathrm{C}$ followed by adding $1.4 \mathrm{~g}$ of both antioxidant and anticorrosion will be mixed in a beaker under stirring for 20 minutes until the additives dissolved and completely dispersed.

Next, the ultramarine powder $5.5 \mathrm{~g}$ was added and mixed by hand until all the powder was wetted out and then mixed for 15 minutes. The product was then cooled to room temperature and set aside for testing (15); its formulation and specification were shown in tables $(3,4)$.

Table (3) Formulation of the greases $S_{0}, S_{1}, S_{2}, S_{3}, S_{4}$ and $S_{5}$

\begin{tabular}{|c|c|c|c|c|c|c|}
\hline \multirow{2}{*}{ Constituent, parts by weight, g. } & \multicolumn{6}{|c|}{ Sample Notation } \\
\hline & $\mathrm{S}_{0}$ & $\mathrm{~S}_{1}$ & $\mathrm{~S}_{2}$ & $\mathrm{~S}_{3}$ & $\mathrm{~S}_{4}$ & $\mathrm{~S}_{5}$ \\
\hline Base lube oil & 167.27 & 167.27 & 167.27 & 167.27 & 167.27 & 167.27 \\
\hline Transformer oil & 83.63 & 83.63 & 83.63 & 83.63 & 83.63 & 83.63 \\
\hline Microcrystalline wax & 109 & 103.6 & 103.6 & 103.6 & 103.6 & 103.6 \\
\hline Ultramarine & - & 5.50 & - & - & - & - \\
\hline Sodium silicate & - & - & 5.50 & - & - & - \\
\hline Silicon dioxide & - & - & & 5.50 & - & - \\
\hline Nano-Magnesium silicate (talc powder). & - & - & - & - & 5.50 & - \\
\hline Nano-Kaolin & - & - & - & - & - & 5.2 \\
\hline Poly oxyethelen sorbiton-nano-palmitate. & 1.4 & 1.4 & 1.4 & 1.4 & 1.4 & 1.4 \\
\hline 2,2 methylen-bis (4-methyle-6-tertiary butyle phenol). & 1.4 & 1.4 & 1.4 & 1.4 & 1.4 & 1.4 \\
\hline
\end{tabular}

Table (4) Specification of the greases prepared $S_{0}, S_{1}, S_{2}, S_{3}, S_{4}$ and $S_{5}$

\begin{tabular}{|c|c|c|c|c|c|c|}
\hline \multirow{2}{*}{ Specifications } & \multicolumn{6}{|c|}{ Sample Notation } \\
\hline & So & S1 & S2 & S3 & S4 & S5 \\
\hline Appearance colour & Pale brown & Blue & Grey-green & Pale yellow- brown & Pale yellow- brown & Pale yellow- brown \\
\hline Oil bleeding & Non & Slight & Non & Non & Slight & Slight \\
\hline $\begin{array}{l}\text { Penetration, } 25^{\circ} \mathrm{C}, 10 \\
\mathrm{~mm} / \text { cone( unworked) }\end{array}$ & 190 & 237 & 235 & 238 & 219 & 211 \\
\hline Dropping point,${ }^{\circ} \mathrm{C}$ & 62 & 64 & 62 & 62 & 56 & 62 \\
\hline Apparent viscosity, at $66^{\circ} \mathrm{C}$, cp & 47.88 & 133.4 & 78.8 & 109.3 & 107.3 & 74.9 \\
\hline Behavior at high temperature & Melted & Melted & Melted & Melted & Melted & Melted \\
\hline Flash point, ${ }^{\circ} \mathrm{C}$,(open) & 182 & 189 & 204 & 188 & 196 & 184 \\
\hline Water repel at $25^{\circ} \mathrm{C}, 1$ hour, $\%$ & 98.5 & 99.5 & 99.2 & 99.8 & 99.9 & 99.8 \\
\hline Code grease according to, NLGI & 4 & 3 & 3 & 3 & 3 & 3 \\
\hline Encapsulation rate & Slow & Fast & Slow & Fast & Fast & Fast \\
\hline Removing with at, $35^{\circ} \mathrm{C}$ & \multicolumn{6}{|c|}{ Benzene, butyl acetate, tetrachloro ethylene, tolwene and xylene } \\
\hline
\end{tabular}

\subsubsection{Preparation of Grease $\left(S_{2}\right)$}

Grease $\mathrm{S}_{2}$ was prepared by heating blend of base lube oil and transformer oil $(250.9 \mathrm{~g})$ to $90-100^{\circ} \mathrm{C}$ and mixed with $103.5 \mathrm{~g}$ of microcrystalline wax under stirring for 40 minutes until wax was dissolved and completely dispersed. Then the sodium silicate $\left(\mathrm{Na}_{2} \mathrm{SiO}_{3}\right) 5.5 \mathrm{~g}$ was added and mixed until all the powdered was wetted out and then mixed for $1 / 4$ hour under strong stirring. The antioxidant $1.4 \mathrm{~g}$ and anticorrosion $1.4 \mathrm{~g}$ were added and mixed for 10 minutes. After cooling to room temperature (15), the formulation and specification of the resulted grease $S_{2}$ were given in tables $(3,4)$. 


\subsubsection{Preparation of Grease $\left(S_{3}\right)$}

The prepared silica $5.5 \mathrm{~g}$ was incorporated into $250.9 \mathrm{~g}$ of lube oil blend and mixed with spoon until all the powder was wetted out and then mixed for $1 / 4$ hour at room temperature. The temperature was raised to $90-100^{\circ} \mathrm{C}$ for $1 / 2$ hour and the $103.50 \mathrm{~g}$ of wax was added under stirring until the wax was dissolved and completely dispersed. Next the antioxidant and anticorrosion additives $1.4 \mathrm{~g}$ for each were added and mixed for 10 minutes followed by cooling the resulting blend to obtain a stable grease (15), its formulation and specification were shown in tables $(3,4)$.

\subsubsection{Preparation of Grease (S4)}

Talc powder, $5.50 \mathrm{~g}$ based on the weight of microcrystalline wax and $250.9 \mathrm{~g}$ lubricating oil base blend were introduced into a glass beaker in the indicated proportions and mixed thoroughly with a spoon at room temperature $25^{\circ} \mathrm{C}$. Mixing continued for sufficient time to produce a homogenous mass. Microcrystalline wax $103.5 \mathrm{~g}$ was added portion wise to the above mixture at $100^{\circ} \mathrm{C}$ with stirring for $1 / 2$ hour until the mixture turned thick.

Heating was stopped to $70^{\circ} \mathrm{C}$, when the content was melted and become homogenous, $1.4 \mathrm{~g}$ of both antioxidant and anticorrosion were added followed by cooling to the normal temperature to obtain the lubricant product greases $\mathrm{S}_{4}(15)$, its formulation and specification were shown in tables $(3,4)$.

\subsubsection{Formulation of Grease(S5)}

Powdered nano-kaolin was incorporated into $250.9 \mathrm{~g}$ of lube oil blend in amount of $5.5 \mathrm{~g}$ by weight at room temperature with stirring for 15 minutes to disperse the powdered.The grease $\mathrm{S}_{5}$ was formulated from the above mixture at $110^{\circ} \mathrm{C}$ which had been thickened with about $103.5 \mathrm{~g}$ of microcrystalline wax with agitation followed by adding $1.4 \mathrm{~g}$ of antioxidant, $1.4 \mathrm{~g}$ of anticorrosion additives under stirring and heating the mixture to about $110^{\circ} \mathrm{C}$ followed by cooling (15), its formulation and specification were shown in tables $(3,4)$.

\section{Results and Discussion}

Organic hydrocarbon greases including rubber, resin or waxes are very widely distributed at industrial branches. They are used in electrical systems and electronic equipments to seal connectors, plug and sockets, to pot cob transformers and capacitors, cables and to prevent electrical leakage (14-17). The known greases used in insulators (13) service are classified on the basis of the formulations into hydrocarbon type (thickened by paraffin, petrolatum, and ceresin), polymer type (thickened by high molecular weight compounds as polymers, rubbers, resins and copolymers), and inorganic type.

Such types of greases should have particular characteristics such as: high flash point, high dielectric properties, high resistance to water, and high dropping point to overcome the problem of grease sliding in insulation in hot weather. They should adhere to insulate and in the same time have mobility at either ambient or discharge temperature, proper formulation which provides resistance to oxidation and corrosion and which also allows stability on storage.

The grease produced, is properly thickened in order to remain in contact with the surface and does not leak out, or be squeezed out. A grease is a two- phase dispersed system of oil gelled with wax.

\subsection{Physico-Chemical Characterization}

Tables (5-7) show the physico-chemical characteristics of the used oils, it's clear that the viscosity of base lube oil grade 260/290 - transformer oil blend is suitable to be used as fluid part in the preparation of grease $27.6 \mathrm{cSt}$, where $50-55 \mathrm{cSt}$ for base lube oil grade $260 / 290$ at $40^{\circ} \mathrm{C}$ which is very large compared with the required value for the insulating oils [transformer oils which are mainly used today $\sim 20 \mathrm{cSt}$ ]. The chief point of difference between the types of greases is the viscosity of the oil used as an ingredient of the grease. Base lube oil grade 260/290 and transformer oil were mixed and used for this purpose.

The suitable flash point of the oils blend is $\left(198^{\circ} \mathrm{C}\right)$ according to ASTM D-93, where the flash point for good insulating oil is not less than $135^{\circ} \mathrm{C}$. The pour point for the base lube oil grade $260 / 290\left(-5^{\circ} \mathrm{C}\right)$ is not suitable according to ASTM D-97 where it is high, but after treating with transformer oil $\left(-20^{\circ} \mathrm{C}\right)$ it becames $\left(12^{\circ} \mathrm{C}\right)$. Studying the distribution of $\% \mathrm{CA}, \% \mathrm{CP}, \% \mathrm{CN}$ is shown. It is deduced that as the $\% \mathrm{CP}$ is greater than $50 \%$, this means that the base lube oil grade (260/290) and base lube oil - transformer oil blend are considered as paraffinic oils.

Table (5) Physico- chemical properties of base lube oil grade (260 / 290)

\begin{tabular}{lll}
\hline Test & $\begin{array}{l}\text { Base lube oil } \\
(\mathbf{2 6 0 / 2 9 0 )}\end{array}$ \\
\hline Kinematic viscosity & \\
At $40^{\circ} \mathrm{C}, \mathrm{cSt}$. & $50-55$ \\
At $100^{\circ} \mathrm{C}, \mathrm{cSt}$. & $6.5-7$ \\
Viscosity index & $90-95$ \\
Flash point, ${ }^{\circ} \mathrm{C}($ open$)$ & 204 \\
Pour point, ${ }^{\circ} \mathrm{C}$ & -5 \\
Colour & 4.5 \\
Total hydroxyl number, & Max. 0.05 \\
Carbon residue, wt. \% & Max. 0.05 \\
Sulphur content, wt. $\%$ & Max. 0.01 \\
Average molecular weight & 392 \\
Refractive index at $20^{\circ} \mathrm{C} \mathrm{n}_{\mathrm{D}}{ }^{20}$ & 1.4880 \\
Density at $20^{\circ} \mathrm{C}, \mathrm{g} / \mathrm{cm}^{3}$ & 0.8799 \\
$\mathrm{n}-\mathrm{d}-\mathrm{m}$ & \\
$\mathrm{C}_{\mathrm{A}} \%$ & 10.92 \\
$\mathrm{C}_{\mathrm{N}} \%$ & 26.48 \\
$\mathrm{C}_{\mathrm{P}} \%$ & 62.60 \\
\hline
\end{tabular}

- Misr petroleum company, Cairo

As the naphthenic percentage of $\mathrm{CN}$ for the oil blend is high, the dielectric properties for this oil are better than the 
first oil grade (260/290) (18). This means that the base lube oil grade (260/290) is not suitable as insulating oil, but after blending it with transformer oil $(12.5 \mathrm{cst})$ it is improved i.e. become suitable as insulating medium.

From the above discussion, it may be pointed outthat the first oil understudy is not suitable for using as fluid part as insulating before carrying out blending (with transformer oil) to overcome the high aromatic contents and to decrease the pour point.

Table (6) Specification of transformer oil

\begin{tabular}{|c|c|}
\hline Specifications & transformer oil \\
\hline \multicolumn{2}{|l|}{ Kinematic viscosity } \\
\hline At $40^{\circ} \mathrm{C} \mathrm{cSt}$ & 12.5 \\
\hline Flash point, ${ }^{\circ} \mathrm{C}$ & 135 \\
\hline Pour point, ${ }^{\circ} \mathrm{C}$ & -20 \\
\hline Density, $\mathrm{g} / \mathrm{cm} 3$, at $20^{\circ} \mathrm{C}$ & 0.8768Max. \\
\hline $\begin{array}{l}\text { Saponification number ,mg. } \\
\mathrm{KOH} / \mathrm{g}\end{array}$ & 0.60Max. \\
\hline Dielectric strength, $\mathrm{KV}$ & 30 \\
\hline
\end{tabular}

- Misr petroleum company, Cairo

Table (7) Specification of base lube oil (260/290) and transformer oil after blending

\begin{tabular}{ll}
\hline Specifications & Oil blending \\
\hline Kinematic viscosity & 27.6 \\
At $40^{\circ} \mathrm{C}, \mathrm{cSt}$. & -12 \\
Pour point, ${ }^{\circ} \mathrm{C}$ & 198 \\
Flash point, ${ }^{\circ} \mathrm{C}($ open$)$ & 0.8773 \\
Density, $\mathrm{g} / \mathrm{cm}^{3}$, at $20{ }^{\circ} \mathrm{C}$ & 400 \\
Average molecular weight & 1.4859 \\
Refractive index, $\mathrm{n}_{\mathrm{D}}{ }^{20}$ & \\
$\mathrm{n}-\mathrm{d}-\mathrm{m}$ & 8.99 \\
$\mathrm{C}_{\mathrm{A}} \%$ & 27.39 \\
$\mathrm{C}_{\mathrm{N}} \%$ & 63.92 \\
$\mathrm{C}_{\mathrm{P}} \%$ & $2: 1$ \\
\hline Transformer oil $:$ Base lube oil & \\
\hline
\end{tabular}

\subsection{FTIR Characterization}

Infrared absorption spectrometry has been applied to determine the functional groups of base lube oil (first oil), transformer oil blend (second oil) and base lube oiltransformer oil blend. The measurement of IR spectra in the range from $4000-500 \mathrm{~cm}^{-1}$ figs $(1,2,3)$ shows that the above oils have low intensity bands in the region $3431-$ $3436 \mathrm{~cm}^{-1}$, indicating low concentrations of $-\mathrm{OH}$ and $-\mathrm{NH}$ groups which have important role in the polarity of oils.

The spectra also shows two strong bands at $2922 \mathrm{~cm}^{-1}$ and $2951 \mathrm{~cm}^{-1}$, resulting from the $\mathrm{CH}_{2}$ and $\mathrm{CH}_{3}$ asymmetric stretching, respectively. A strong band at $1459 \mathrm{~cm}^{-1}$, which is due to $\mathrm{C}-\mathrm{H}$ asymmetric bending vibrations of methyl and methylene groups. In addition, the weak band that is obtained at $1374 \mathrm{~cm}^{-1}$ may be attributed to either C-N stretching vibration of aromatic amines or $\mathrm{C}-\mathrm{H}$ symmetric bending vibration of methyl groups and a weak band at $1605 \mathrm{~cm}^{-1}$ had appeared which is due to the stretching vibration of $\mathrm{C}=\mathrm{C}$ aromatic

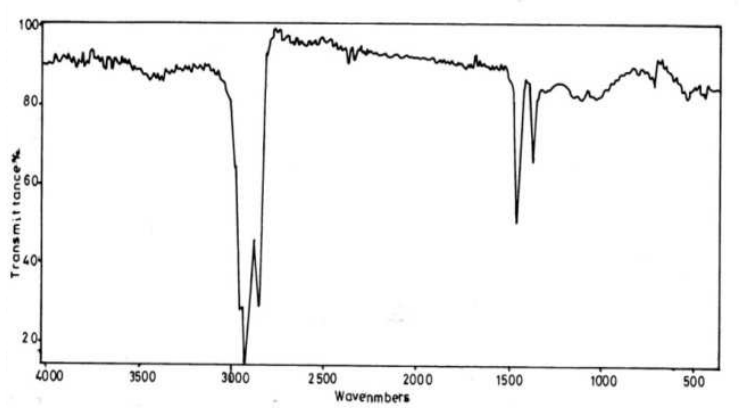

Fig (1) IR Spectrum for base lube oil grade (260/290)

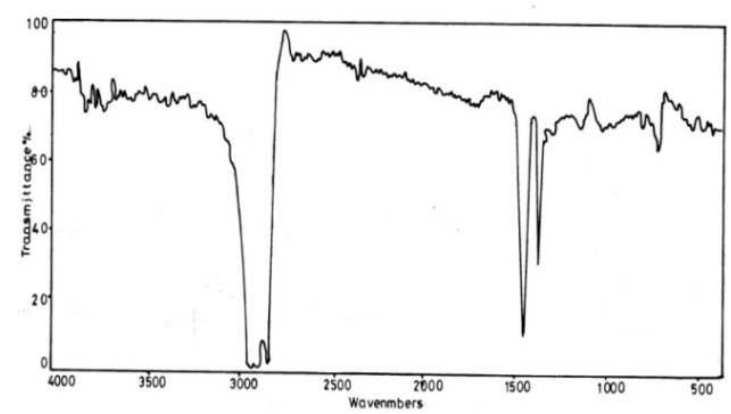

Fig (2) IR Spectrum for transformer oil

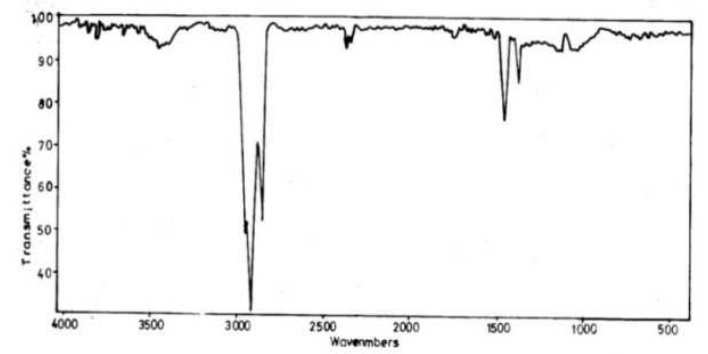

Fig (3) IR Spectrum for base lube oil grade (260/290) and transformer oil after blending

\subsection{Characteristics of Microcrystalline wax}

\subsubsection{Physico-Chemical Characterization}

The data in table (8) is presenting the physico-chemical properties of microcrystalline wax showing that having high molecular weight (large hydrocarbon chain 40) 560 and having melting point of range of 80-81 which give rise to be used in coating applications, also the fine crystal structure enables microcrystalline wax to bind solvent or oil and prevent the sweating-out of compositions. 
Table (8) Physical properties of microcrystalline wax

\begin{tabular}{ll}
\hline Properties & wax \\
\hline Melting range, ${ }^{\circ} \mathrm{C}$ & $80-81$ \\
Oil content,$\%$ & 0.5 \\
Needle penetration, $0.1 / \mathrm{mm}$ at $25^{\circ} \mathrm{C}$ & $10-11$ \\
Flash point, ${ }^{\circ} \mathrm{C}$ (open) & 228 \\
Colour & 0 (white) \\
Mean molecular weight & 560 \\
Average number of carbon atoms. & $\sim 40$ \\
Density, g/cm ${ }^{3}$, at $20^{\circ} \mathrm{C}$ & 0.9002 \\
Appearance & Odorless, \\
& Opaque Malleable, \\
Solubility & Benzene, ether, chloroform \\
\hline
\end{tabular}

\subsubsection{FTIR Characterization}

The FTIR spectra of the microcrystalline wax fig (4)indicates a sharp band in the region of (3000-2850 $\left.\mathrm{cm}^{-1}\right)$ associating for stretching vibration of $\mathrm{C}-\mathrm{H}$ aliphatic and a band in the region $\left(1450-1375 \mathrm{~cm}^{-1}\right)$ for stretching vibration of methyl and methylene groups.

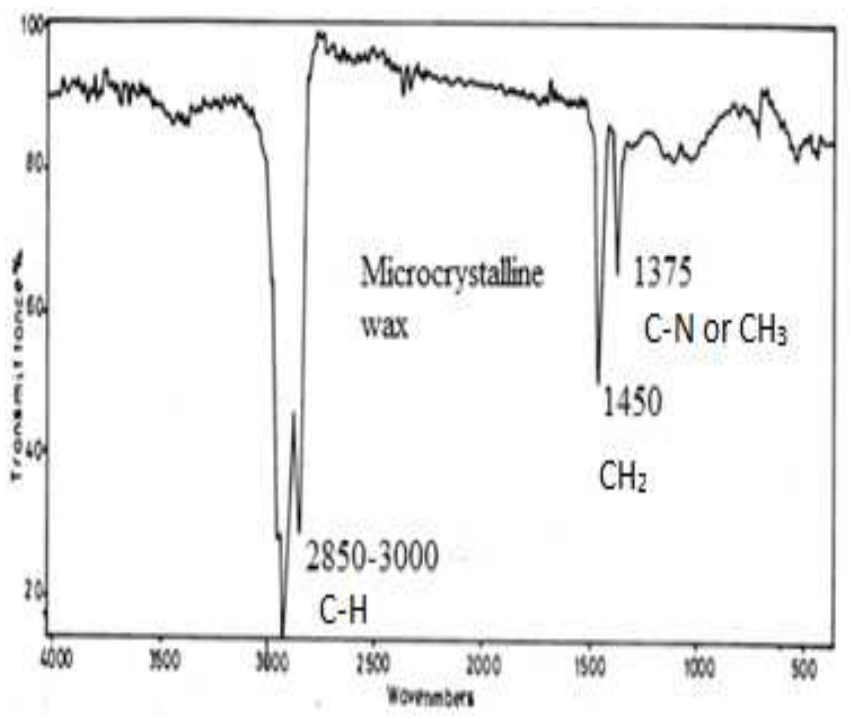

Fig (4) IR Spectrum for microcrystalline wax

\subsubsection{FTIR Characterization of Silica from Rice Husk}

The FTIR spectra of the prepared silica $\mathrm{SiO}_{2}$ from rice husk fig (5), in the frame work region (4000-500 $\left.\mathrm{cm}^{-1}\right)$, indicates absorption observed at $\left(1090-1115 \mathrm{~cm}^{-1}\right)$.This band is associated with the $\mathrm{Si}-\mathrm{O}$ stretching modes in silica $\mathrm{Si}-\mathrm{O}$ unit.

\subsection{The Dielectrical Properties of the Prepared Greases}

The dielectric constant $\varepsilon$, dielectric loss $\varepsilon^{\prime \prime}$ and volume resistivity of the prepared greases $\mathrm{S}_{0}, \mathrm{~S}_{1}, \mathrm{~S}_{2}, \mathrm{~S}_{3}, \mathrm{~S}_{4}$, and $\mathrm{S}_{5}$ are studied at temperature $35^{\circ} \mathrm{C}$ in the frequency range from $1 \mathrm{KHz}$ to $1000 \mathrm{KHz}$. The results obtained for $\varepsilon, \varepsilon^{\prime \prime}$ and volume resistivity vs. frequency for these samples were shown in tables $(9,10)$ and figs $(6,7,8)$. It is evident from these figures and tables that, $\varepsilon^{\prime \prime}$ decreases with increasing frequency.

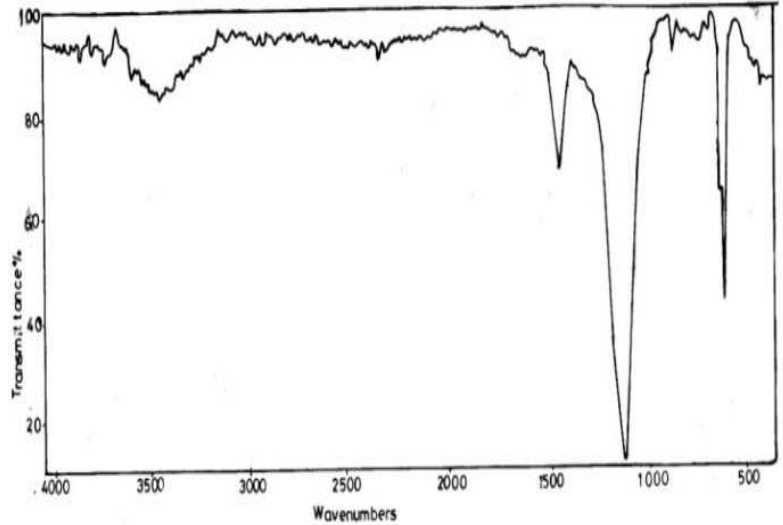

Fig. (5) IR spectrum of silicon dioxide

The fundamental properties of insulating greases are the electrical properties (dielectric constant $\varepsilon$, dielectric loss $\varepsilon "$ and volume resistivity)

The data obtained in tables $(9,10)$ and figs $(5,6)$ shows that the dielectric constant of the samples are in the order $\mathrm{S}_{4}$ more electrical insulating than $S_{3}>S_{5}>S_{2}>S_{1}>S_{0}$. Since $S_{4}$ has the lowest value of dielectric constant (1.9011) at frequency $1 \mathrm{KHz}$ at $35^{\circ} \mathrm{C}$. The dielectric loss decreases with increasing frequency. The $\varepsilon^{\prime \prime}$ of the samples is in order $\mathrm{S}_{4}$ more electrical insulating than $\mathrm{S}_{3}>\mathrm{S}_{5}>\mathrm{S}_{2}>\mathrm{S}_{1}>\mathrm{S}_{0}$. Since $\mathrm{S}_{4}$ has the lowest value of $\varepsilon^{\prime \prime}(0.773)$ at $1 \mathrm{KHz}$.

On the other hand the change of the volume resistivity of these samples $\mathrm{S}_{0}, \mathrm{~S}_{1}, \mathrm{~S}_{2}, \mathrm{~S}_{3}, \mathrm{~S}_{4}$, and $\mathrm{S}_{5}$ represented in table (10) and fig (7), showing that the volume resistivity decreases with increasing frequency. Since $\mathrm{S}_{4}$ has the highest value of volume resistivity $\left(0.7 \times 10^{12} \mathrm{ohm} . \mathrm{cm}\right.$.

The volume resistivity of the samples is in the order $\mathrm{S}_{4}$ more electrical insulating than $\mathrm{S}_{3}>\mathrm{S}_{5}>\mathrm{S}_{2}>\mathrm{S}_{1}>\mathrm{S}_{0}$.

This proves that, the dielectrically properties of sample $S_{4}$ greases is formulated from nano-talc powder (magnesium silicate) with the structure $\mathrm{Mg}_{2} \mathrm{Si}_{4} \mathrm{O}_{10}(\mathrm{OH})_{2}$ or $\mathrm{H}_{2} \mathrm{Mg}_{2}$ $\left(\mathrm{SiO}_{3}\right)_{4}$ which is composed from $\left(\mathrm{MgO} 31.88 \%, \mathrm{SiO}_{2}\right.$ $63.77 \%, \mathrm{H}_{2} \mathrm{O} 4.75 \%$ ) i.e. $\mathrm{Mg}^{+2} \mathrm{Si}^{+4} \mathrm{O}^{-2} \mathrm{OH}^{-1}$ due to ion $\mathrm{Mg}^{+2}$ blocks the flow of current from one part of the device to another i.e. blocks the migration path of the electrons.

The improvement occurs in electrical insulation due to the presence of silicate group, where silicate consists of silicon with oxygen as the ligand silicate anions, with a negative net electrical charge, it must change balancing by other cations to make an electrically neutral compound. Moreover, talc consists of a two silicate layers are bonded together by weak Vander Waals forces.

The data obtained in tables $(9,10)$ and figs $(5,6$, and 7$)$ shows that sample $\mathrm{S}_{3}$ has silica dioxide well dielectrically properties. This may be attributed to the $\mathrm{SiO}_{2}$ produced from rice husk which is a giant covalent structure. The strong bonds in three dimensions make it a hard, do not conduct electricity, there are not any delocalized electrons. All the electrons are held tightly between the atoms, and are not free to move. 
It is evidence from tables $(9,10)$ and figs $(5,6$ and 7$)$ that the sample $\mathrm{S}_{5}$ (formulated from $\mathrm{S}_{0}$ and nano kaolin) is dielectric this may be due to the structure of nano kaolin

$$
\mathrm{Al}_{2} \mathrm{O}_{3} \cdot 2 \mathrm{SiO}_{2} \cdot 2 \mathrm{H}_{2} \mathrm{O} \stackrel{300^{\circ} \mathrm{C}}{\longrightarrow} \mathrm{Al}_{2} \mathrm{O}_{3} \cdot 2 \mathrm{SiO}_{2}
$$

(39\% $\mathrm{Al}_{2} \mathrm{O}_{3}, 46.3 \%$ Silica, $13.9 \mathrm{H}_{2} \mathrm{O}$ ). The dielectric is attributed to the presence of $\mathrm{Al}_{2} \mathrm{O}_{3}$, because of possessing strong interatomic bonding; it gives to its desirable material characteristics. Also, this may be due the presence of silica group in the structure of nano kaolin.

On the other hand, the dielectric properties of $\mathrm{S}_{2}$ (formulated from $\mathrm{S}_{0}$ and sodium silicate $\mathrm{Na}_{2} \mathrm{SiO}_{3}$ ) are better than the sample $S_{1}$ (formulated from $S_{0}$ and ultramarine, $\left.\mathrm{Na}_{8-10} \mathrm{Al}_{16} \mathrm{Si}_{6} \mathrm{O}_{24} \mathrm{~S}_{2-4}\right)$ i.e. structure of ultramarine contains $\mathrm{SiO}_{2}, \mathrm{Al}_{2} \mathrm{O}_{3}$.

The sample $S_{1}$ and $S_{2}$ have dielectric properties, despite the presence of sodium ions $8 \mathrm{Na}^{+}$in case of ultramarine, $2 \mathrm{Na}^{+}$ion in case of sodium silicate (sodium are classified as conductors because their outer electrons are not tightly bound valance electrons).

This could be attributed to Mott insulation theory (19-21) which say that there is class of materials that are expected to conduct electricity under conventional band theories, but which in fact turn out to be insulators when measured. This effect is due to electron-electron interactions which are not considered in the formulation band theory. The presence of silicate group and silica group beside alumina in its structure improve the electrical insulating character.

This proves that, the dielectric properties of grease $\mathrm{S}_{4}$ improve gradually with adding nano -talc or $\mathrm{S}_{3}$ with silica, $\mathrm{S}_{5}$ with nano-kaolin, $\mathrm{S}_{2}$ with sodium silicate or $\mathrm{S}_{1}$ with ultramarine. i.e. all samples have dielectric properties better than $\mathrm{S}_{0}$.

Table (9) Dielectric measurement of greases $S_{0}, S_{1}, S_{2}, S_{3}, S_{4}$ and $S_{5}$

\begin{tabular}{|c|c|c|c|c|c|c|}
\hline \multirow{2}{*}{ Specifications } & \multicolumn{6}{|c|}{ Sample Notation } \\
\hline & $\mathrm{S}_{0}$ & $\mathrm{~S}_{1}$ & $\mathrm{~S}_{2}$ & $\mathrm{~S}_{3}$ & $\mathrm{~S}_{4}$ & $\mathrm{~S}_{5}$ \\
\hline \multicolumn{7}{|c|}{ Permativity $\left(\varepsilon^{\prime}\right)$ at frequency, } \\
\hline $1 \mathrm{KHz}$ & 2.0798 & 2.074 & 2.065 & 1.92 & 1.9011 & 1.9314 \\
\hline $10 \mathrm{KHz}$ & 2.0761 & 2.070 & 2.05 & 1.916 & 1.9018 & 1.92 .09 \\
\hline $100 \mathrm{KHz}$ & 2.0716 & 2.026 & 2.010 & 1.919 & 1.9023 & 1.923 \\
\hline $1000 \mathrm{KHz}$ & 2.0589 & 2.010 & 1.957 & 1.860 & 1.7044 & 1.9113 \\
\hline \multicolumn{7}{|c|}{ Dielectric $\operatorname{loss}\left(\varepsilon^{\prime \prime}\right)$ at frequency, } \\
\hline $1 \mathrm{KHz}$ & 0.6429 & 0.4946 & 0.4455 & 0.3759 & 0.0773 & 0.3946 \\
\hline $10 \mathrm{KHz}$ & 0.2344 & 0.2911 & 0.2600 & 0.153 & 0.0396 & 0.229 \\
\hline $100 \mathrm{KHz}$ & 0.0813 & 0.0638 & 0.0496 & 0.046 & 0.0048 & 0.0519 \\
\hline $1000 \mathrm{KHz}$ & 0.0216 & 0.0200 & 0.0014 & 0.0065 & 0.0066 & 0.0021 \\
\hline
\end{tabular}

At temperature $35^{\circ} \mathrm{C}$

Table (10) Volume resistivity measurements of greases $S_{0}, S_{1}, S_{2}, S_{3}, S_{4}$ and $S_{5}$

\begin{tabular}{llllll}
\hline Specifications & \multicolumn{2}{l}{ Sample Notation } & & & \\
& $\mathrm{S}_{0}$ & $\mathrm{~S}_{1}$ & $\mathrm{~S}_{2}$ & $\mathrm{~S}_{3}$ & \\
\hline Volume resistivity .Ohm.cm, at & & & & & \\
$35^{\circ} \mathrm{Cat}$ frequency, & & & & \\
$1 \mathrm{KHz}$ & $0.23 \times 10^{10}$ & $\times 10^{11} 0.1$ & $\times 10^{11} 0.5$ & $0.7 \times 10^{11}$ & $0.7 \times 10^{12}$ \\
$10 \mathrm{KHz}$ & $0.913 \times 10^{9}$ & $\times 10^{11} 0.039$ & $\times 10^{11} 0.44$ & $\times 10^{11} 0.53$ & $\times 10^{11} 0.99$ \\
$100 \mathrm{KHz}$ & $0.305 \times 10^{9}$ & $0.13 \times 10^{10}$ & $0.5 \times 10^{10}$ & $\times 10^{10} 0.5$ & $\times 10^{11} 0.05$ \\
$1000 \mathrm{KHz}$ & $0.116 \times 10^{9}$ & $\times 10^{9} 0.88$ & $\times 10^{10} 0.07$ & $\times 10^{10} 0.01$ & $0.06 \times 10^{11}$ \\
\hline
\end{tabular}

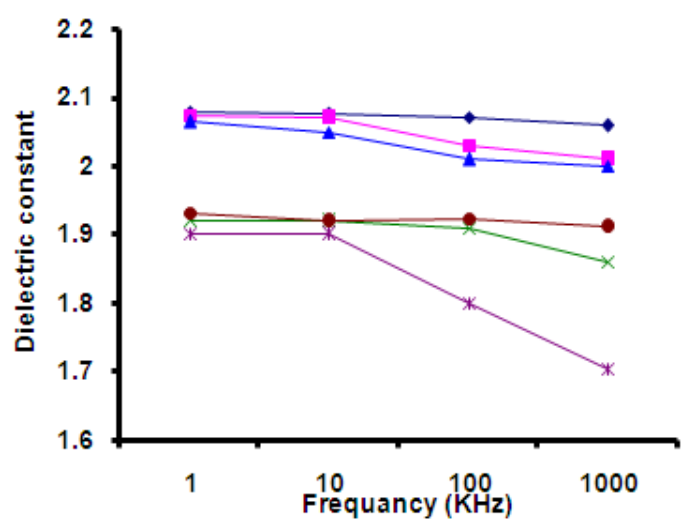

Fig (5) The dielectric constant $\left(\varepsilon^{\prime \prime}\right)$ vs. frequency at temperature $35^{\circ} \mathrm{C} S_{0}, S_{1}$, $S_{2}, S_{3}, S_{4}$ and $S_{5}$ greases

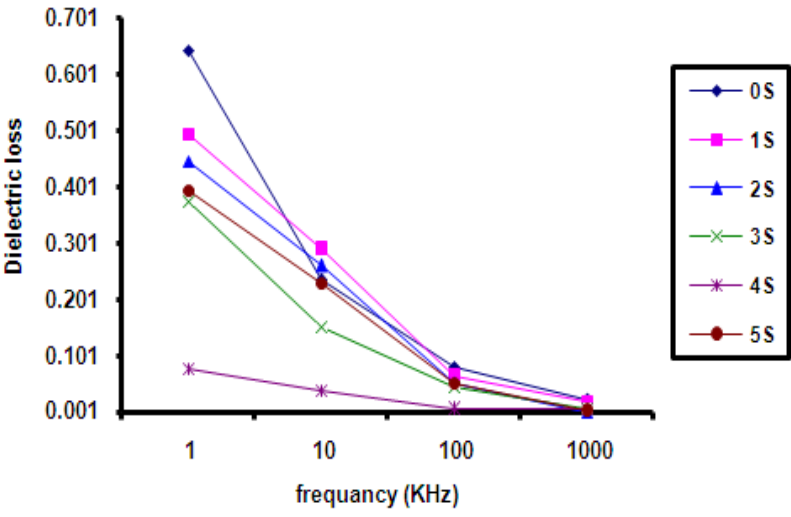

Fig (6) The dielectric loss $\left(\varepsilon^{\prime \prime}\right)$ vs. frequency at temperature $35^{\circ} \mathrm{C} \mathrm{SO}$, S1, S2, S3, S4 and S5 greases 


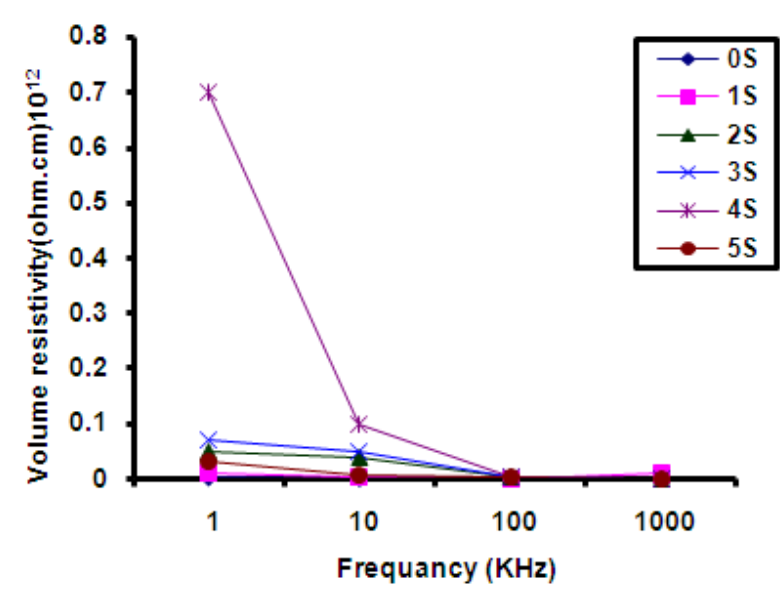

Fig (7) The relation between volume resistivity and frequency at temperature $35^{\circ} \mathrm{C}$ for $S_{0}, S_{1}, S_{2} S_{3}, S_{4}$ and $S_{5}$ greases

\section{Conclusion}

- Grease which has inorganic fillers in its composition has better physicochemical properties than wax gel grease (grease without any filler) which means that all types of fillers affect well to the wax gel.

- According to the dielectric properties (electrical insulation properties) that include dielectric constant, dielectric loss and volume resistivity, kaolin grease is the best one to be used as a cable filling material.

- Grease contains silica from rice husk which is better for insulation than talc grease, sodium silicate and ultramarine greases.

\section{References}

[1] P. Jarrod; Step-By-Step Grease Selection, Machinery Lubrication Magazine, Issued Number 200509, Sept. (2005).

[2] Y. Toomas; Oil or Greases Lubrication, Issued on December 3 (2001).

[3] Georg, G.C. and Westfield, N.S., U.S. Patent, 3639237, Issued on Feb. 1, (1972).

[4] L. Meals; Reinhold Plastic Applications Series, Silicon; Reinhold Pub. Corp. New York, P. 84, 204-205, (1961).

[5] Gunderson and Hart, Synthetic Lubricants, Reinhold - Puble. Corp. New York, P. 259-263, 317-319, 355-356, 470-473, (1962).
[6] L. Jan, and B.; Seven, Hand Book of Grease Applications, Industrial Lubrication and Tribology, 52, Issue 5, P. 221 (2000).

[7] V.P. Sukhanov, Petroleum Processing, Mir Publishers Moscow, P. 17, (1982)

[8] M. Brauer ; Chu and Yuanc, U.S. Patent, 5348669, Sep. 20, (1994).

[9] Annual Report Conference on Publication Date 14-17 Oct., Pages 45. Electrical Insulation and Dielectric Phenomena, CEIDP (2007).

[10] P.J. Lambeth, and J.S.T. Looms; Surface Coating for H.V. Insulators in Polluted Areas, Inst. P., Proc. IEE, Vol.113, No. 5, P. 861, May (1966).

[11] T.S. Forest, P.J. Lambeth, and D.F. OAKeshott; Research on the Performance ofHigh - Voltage Insulators in Polluted Atmospheres, Proc. IEE, 107A, P. 172, (1960).

[12] C.H. Gartisde , A.C. Levy, and C.R. Taylor; U.S. Patent, 4701016, Issued on October 20, (1987).

[13] M.A.E. Youssif; Evaluation of Some Prepared Greases Based on Petroleum Wax Gel, M.Sc. Thesis, Faculty of Science, Al - Azhar University, Cairo, Egypt, (2009).

[14] A.A.M. Daifullah, N.S. Awwad and S.A. El - Reefy; Purification of Wet Phosphoric Acid from Ferric Ions Using Modified Rice Husk, Chemical Engineeringand Processing, 43 P.193 (2004).

[15] A.M. Hassan; Greases From Some Petroleum and Coal Tar Products, M.Sc. Thesis, Faculty of Science, Al - Azhar University, Cairo, Egypt, (1978).

[16] G.D. Brown, and M.J. Keogh; U.S. Patent, 6120897, Issued on Sept. 16, (2000).

[17] A. R. El - Adly and A. S. Ward; Egypt. J. Petrol. 13, No. 1, P. 69(2004).

[18] M.A. Youssif, M.Y. Abed, and I.M. EL-Anwar; "Preparation and Dielectric Properties of Methylemethacrylate-Parabanic Acid Polymer Using Some Additives" Egypt. J. Petrol.2, P. 1-8, 3 March (1993).

[19] Petroleum Technology, an Introductory Course, Crude Oil and Petroleum Company Alexandria, Vol. 8, P. 168.

[20] Wikipedia, The Free Encyclopedia, Mott insulators.

[21] Y. Kohsaka, C. Taylor, and P.E.A. Wahl; "How Cooper Pairs Varnish Approaching the Mott Insulator in $\mathrm{Bi}_{2} \mathrm{Sr}_{2} \mathrm{CaCu}_{2} \mathrm{O}_{8}$." P. 1072. 28 August (2008). 